\title{
WORN VEHICLE TYRES IN POLISH ROAD CONSTRUCTION - ECOLOGY, LAW, USE, AND ECONOMICS
}

Ewa Ołdakowska, PhD (ORCID: 0000-0002-5437-2470) - Politechnika Białostocka

Correspondence address:

Bialystok University of Technology

Wiejska 45 Street, 15- 351 Białystok, Poland

e-mail: e.oldakowska@pb.edu.pl

ABSTRACT: The recycling of worn tyres is enforced primarily by legal regulations, but it is also motivated by ecological and economic reasons. In Poland, recovery of rubber materials makes it possible to obtain materials of good quality and very broad applications, e.g. for plastic road surface or production of so-called rubber asphalt, used for the grindable layer of roads, as well as for innovative materials intended for filling bridge abutments of integrated bridges. The paper considers the financial aspect of using disintegrated rubber waste by analysing the cost of replacing the binder with different amounts of rubber dust $(10 \%, 12 \%, 14 \%, 16 \%)$. With the assumptions made, the analysis allows for concluding that with an increase in the content of the rubber additive, the cost of the binder changes.

KEYWORDS: recycling, road construction, rubber, sustainable development 


\section{Introduction}

The recycling of worn tyres is enforced primarily by legal regulations, but it is also motivated by ecological and economic reasons. In Poland, the recovery of rubber materials makes it possible to obtain good quality materials with a very wide range of applications. End-of-life tyres, due to their diverse composition: rubbers (natural rubber, nitrile butadiene rubber, ethylene-propylene-diene-monomer rubber), fillers, antioxidants, antiozonants, and curing agents (Fazli \& Rodrigue, 2020) are resistant to biodegradation, photochemical decomposition, and thermal degradation (Fukumori et al., 2002, Karger-Kocsis et al., 2013). Nevertheless, they can be successfully recycled to recover energy (Amari et al., 1999, Ramarad et al., 2015) or perform pyrolysis (Shah et al., 2007). They are also used as a fuel source in cement furnaces or as fuel for the production of steam, electricity, paper, lime, and steel. Unfortunately, burning tyres as fuel release dangerous gases and recovers only $25 \%$ of the energy used to make rubber (Van Beukering \& Janssen, 2001). In addition, pyrolysis of waste tyres decomposes the rubber component into soot, zinc, sulphur, steel, oils, and gas, and the high operating costs of pyrolysis plants limit the widespread use of this method (Ilkılıç \& Aydın, 2011). Several environmentally friendly recycling techniques have been developed, such as triboelectric separation, foam flotation, and laser breakthrough spectroscopy. However, those methods are expensive, and the recycled rubbers vary in purity, size, shape, and surface topography quality (Adhikari et al., 2000, Fang et al., 2001, Singh et al., 2017). Vulcanised rubber wastes are difficult to recycle, nevertheless as very durable, strong, and flexible materials, they may be used as fillers in the production of composites (Medina et al., 2018) or components of asphalt mixtures (Kaloush, 2003, Plewa, 2014, Radziszewski et al., 2017, Sybilski, 2009).

The aim of this paper is to approach the problem of worn tyres in a broader scientific-practical and financial-economic context, taking into account the legal framework and ecological aspects.

\section{Legal aspects of using worn vehicle tyres in the construction}

With the increasing number of vehicles on the roads each year, the number of tyres in circulation is also increasing. In 2018 alone, those were over 274,000 tonnes of tyres $(274,448$ to be exact) (Statistics Poland) that are expected to be disposed of in the future. It will take more than 100 years for worn tyres to decompose, so it is important to put the mechanisms allowing to reuse them in $100 \%$ in place. 
As implemented in the national legislation systems, the principles of waste management are closely related to the general principles of environmental law applicable at the international level.

In Poland, the management of waste rubber from worn vehicle tyres is regulated by laws that follow three important EU directives:

1) Landfill 1999/31/EC (Council Directive 99/31/EC of April 26, 1999, on the landfill of waste), which bans the landfilling of whole vehicle tyres from July 2003 and of disintegrated parts from July 2006, and obliges all Member States to implement these bans.

2) End-of-Life Vehicle 2000/53/EC (Directive 2000/53/EC of the European Parliament and of the Council of September 18, 2000, oend-of-lifefe vehicles) sets out how end-of-life vehicles should be dealt with, imposing on European vehicle manufacturers an obligation to recover $85 \%$ and recycle $80 \%$ of the vehicle mass from 2006, and to recover $95 \%$ and recycle $85 \%$ from 2015, respectively. According to the directive, the vehicles should have all tyres removed before scrapping.

3) Waste Incineration 2000/73/EC obliges cement plants to use the worn vehicle tyres as an alternative fuel to impose higher limits on harmful waste gas emissions of $\mathrm{NO}_{\mathrm{x}}$ up to $800 \mathrm{mg} / \mathrm{m}^{3}$ (Journal of Laws 2014 pos. 1546).

The first Polish law compliant with (Council Directive 99/31/EC of April 26,1999 , on the landfill of waste), which prohibited the storage of worn vehicle tyres, was the Act of April 27, 2001, on waste (Journal of Laws 2001 No. 62, pos. 628). Another act regulating their management was the Act of May 11,2001 , on the duties of entrepreneurs with respect to the management of certain types of waste and product fees (Journal of Laws 2001 No. 63, pos. 639). It set out the principles for determining and collecting the product fee - in order to prevent waste generation, limit its negative impact on the environment, and ensure a high level of waste recovery and recycling. Another act, the so-called "cleaning act", was the act of February 72003 (Journal of Laws No. 7, pos. 78, from 2003), introducing the obligation to recycle the worn tyres from 2004 . The target was set at $15 \%$ in 2007 , where tyre retreading was not considered recycling but recovery. Further legal acts of significant importance for worn tyre management were: The Act on international trade in waste of July 302004 (Journal of Laws No. 191, pos. 1956, from 2004) and the "wreck" act (consistent with (Directive 2000/53/EC of the European Parliament and of the Council of September 18, 2000, on end-oflife vehicles), Journal of Laws 2005 No. 25, pos. 202) concerning end-of-life cars. 


\section{Examples of the use of worn vehicle tyres in Polish road construction}

The use of worn, used tyres in the Polish road construction industry includes the production of the so-called rubber asphalt (AMG), used for the asphalt grindable layer of the road. Vehicle tyres are subjected to the same weather factors as road surfaces, and their composition and properties make rubber a good modifier for asphalt. The "rubber asphalt" is a mixture of road asphalt and disintegrated rubber from vehicle tyres (at least $15 \%$ by weight), which swells when reacting with hot asphalt. Disintegrated rubber from vehicle tyres can be introduced in two ways, dry or wet. The dry method consists in adding rubber granulate to the mineral mixture in order to replace part of the aggregate, while the wet method consists in modifying the binder with rubber dust beforehand and introducing the finished rubber and asphalt binder into the mineral mixture. The addition of rubber to asphalt improves road quality, ageing resistance, and durability, as well as increasing traction between the surface and the tyre while lowering noise levels and reducing the braking distance for cars. Such technology is already used in the USA, Spain, the UK and China. Several tens of kilometres of roads in Poland (in several locations) were also built. This technology is characterised by improved parameters (in relation to other existing technologies) in terms of:

- longer service life,

- resistance to thermal cracking (mixtures used for the grindable layer do not crack at all at low temperatures, or cracks develop much more slowly, and the layer maintains its structural integrity almost to the very end),

- lower values of stiffness modulus and higher stress relaxation capacity,

- increased resistance to fatigue cracking and rebound cracking,

- increased resistance to permanent deformation caused by high temperature,

- improved anti-slip properties (the rubber particles on the surface of the aggregate grains increase friction between the tyre and the road), resulting in shorter braking distance,

- noise reduction (the layer, thanks to its structure, reduces the noise level from vehicles by 2-5 dB on average).

Another application of worn tires in Polish road construction is their use in the form of rubber granulate in the poroelastic pavement. In the period from May 1, 2018, to April 30, 2021, a project with the acronym SEPOR (Safe, Environmentally Friendly Poroelastic Road Pavement) has been implemented with the aim of developing an innovative poroelastic road pavement, characterised by very low noise, water permeability, suppression of liquid fuel spill fires, as well as good rolling resistance, and anti-slip properties. The 
poroelastic pavements are pavements that are currently in the experimental phase, and so far, it has not been possible to develop this type of pavement with the required durability. The consortium implemented the project: Gdańsk University of Technology, Białystok University of Technology, MTM S.A. from Gdynia. The 7FP PERSUADE (Poroelastic Road Surface: an innovation to Avoid Damages to the Environment) project, started in 2009, ended in 2015 as a step in improving the poroelastic pavements. The project involved two partners from Poland: Gdańsk University of Technology and the Road and Bridge Research Institute in Warsaw. The poroelastic grindable layers allow for a significant reduction in traffic noise (even up to $12 \mathrm{~dB}$ in comparison with the commonly used traditional SMA11 type pavements) and may prove to be more effective and less expensive than acoustic screens, especially in urban conditions.

Moreover, the poroelastic pavements make it difficult, if not impossible, for liquid fuel spills to spread fire, which makes them the pavements for use in tunnels, service stations, and terminal areas. The research in a number of SEPOR projects aims to improve mixture composition, use of new binders made from highly modified asphalts, and a detailed study of the influence of the manufacturing process on the durability of poroelastic pavement, as well as the strengthening of the connection between the poroelastic pavement and the layer below. It should eliminate the problem of the interlayer connection being torn apart by tangential forces occurring at the contact between the layers. Moreover, the anti-slip properties of the road pavement have been optimised. The experimental sections were built and subjected to typical traffic loads and weather conditions as part of the project.

The development of non-expensive, environmentally friendly, and innovative materials derived from recycled vehicle tyres for backfilling the bridge abutments is the aim of another project funded by the National Centre for Research and Development and carried out by a consortium of four partners: Rzeszów University of Technology, Promost Consulting, Remost Dębica, Geotech Rzeszów. The project's duration is the two stages - a research stage that fell between August 2015 and February 2018, and an implementation stage covering six months: March-August 2018. 


\section{The financial aspect of using the disintegrated worn car tyres for asphalt binders modification}

The use of rubber dust to modify asphalts is undoubtedly a significant improvement in their properties, the "second life of the tyre", and the associated financial relationships.

In order to establish these relationships, the cost calculations have been carried out for substituting the binder with rubber. The original percentage of the binder contained in asphalt mixtures of the types of AC 11 and SMA 11 asphalt concrete, designed for the grindable layer of road pavements loaded with KR3 and KR4 traffic, has been used to evaluate the cost of the binder. The asphalt mixtures have been designed following (WT-2 2014). A mixture of aggregates (lime dust, broken sand $0 / 2$, grit $2 / 5.6$, grit $2 / 8$, grit $4 / 8$, grit $8 / 11$ ) of constant granulometric composition and road asphalt $50 / 70$ has been used for their construction. The list of compositions of asphalt mixtures is presented in table 1 .

Table 1. List of compositions (share in \%) of asphalt mixtures

\begin{tabular}{llll}
\hline & \multicolumn{3}{l}{ List of compositions (share in \%) of asphalt mixtures } \\
\cline { 2 - 4 } Type of material & $\begin{array}{l}\text { AC 11 50/70 } \\
\text { KR 3-4 }\end{array}$ & $\begin{array}{l}\text { SMA 11 50/70 } \\
\text { KR 3-4 (I) }\end{array}$ & $\begin{array}{l}\text { SMA 11 50/70 } \\
\text { KR 3-4 (II) }\end{array}$ \\
\hline $\begin{array}{l}\text { Asphalt } \\
\text { Limestone dust }\end{array}$ & 5.80 & 6.60 & 7.20 \\
Broken sand & 7.50 & 10.27 & 8.40 \\
O/2 & & & \\
Grit 2/5.6 & 28.30 & 6.53 & 15.80 \\
Grit 2/8 & & 23.33 & 4.60 \\
Grit 4/8 & 37.70 & 10.27 & 25.10 \\
Grit 8/11 & & 43.00 & 38.90 \\
Total & 20.70 & 100.00 & 100.00 \\
\hline
\end{tabular}

Source: author's work.

The cost analysis of binder modified with various content of rubber dust (in the amount of $10 \%, 12 \%, 14 \%, 16 \%$ in relation to binder weight) has been performed using prices included in the monthly information (Informacja miesięczna ...) and quarterly information (Informacja o cenach ...) of "Sekocenbud" publishing house. The price of granulate has been established upon the basis of sale offers (unit prices fluctuated around 700 PLN per Mg). The price does not include the purchase and external transport costs, which should be calculated individually according to the actual conditions. The unit price of the binder is 1940 [PLN/t]. Lists of costs of replacing the binder with various amounts of disintegrated worn vehicle tyres are shown in tables 2,3 , and 4 . 
Table 2. List of costs of replacing the binder (originally used in mineral and asphalt mixture AC 11 50/70 KR 3-4) with various content of rubber additive

\begin{tabular}{llllll}
\hline \multirow{2}{*}{ Type of material } & \multicolumn{5}{l}{ Costs [in PLN] of replacing the binder (originally used in the asphalt mixture AC } \\
& \multicolumn{1}{l}{$\mathbf{1 1}$ 50/70 KR 3-4) with rubber additive in amount of: } \\
\cline { 2 - 6 } & $\mathbf{0} \%$ & $\mathbf{1 0 \%}$ & $\mathbf{1 2 \%}$ & $\mathbf{1 4 \%}$ & $\mathbf{1 6 \%}$ \\
\hline Bitumen & 112.52 & 101.27 & 99.02 & 96.77 & 94.52 \\
Rubber additive & - & 4.06 & 4.87 & 5.68 & 6.50 \\
Total & 112.52 & 105.33 & 103.89 & 102.45 & 101.01 \\
\hline
\end{tabular}

Source: author's work.

Table 3. List of costs of replacing the binder (originally used in mineral and asphalt mixture SMA 11 50/70 KR 3-4) with various content of rubber additive

\begin{tabular}{|c|c|c|c|c|c|}
\hline \multirow[t]{2}{*}{ Type of material } & \multicolumn{5}{|c|}{$\begin{array}{l}\text { Costs [in PLN] of replacing the binder (originally used in the asphalt mixture } \\
\text { SMA } 11 \text { 50/70 KR 3-4) with rubber additive in amount of: }\end{array}$} \\
\hline & $0 \%$ & $10 \%$ & $12 \%$ & $14 \%$ & $16 \%$ \\
\hline Bitumen & 128.04 & 115.24 & 112.68 & 110.11 & 107.55 \\
\hline Rubber additive & - & 4.62 & 5.54 & 6.47 & 7.39 \\
\hline Total & 128.04 & 119.86 & 118.22 & 116.58 & 114.95 \\
\hline
\end{tabular}

Source: author's work.

Table 4. List of costs of replacing the binder (originally used in mineral and asphalt mixture SMA 11 50/70 KR 3-4) with various content of rubber additive

\begin{tabular}{|c|c|c|c|c|c|}
\hline \multirow[t]{2}{*}{ Type of material } & \multicolumn{5}{|c|}{$\begin{array}{l}\text { Costs [in PLN] of replacing the binder (originally used in the asphalt mixture } \\
\text { SMA } 11 \text { 50/70 KR 3-4) with rubber additive in amount of: }\end{array}$} \\
\hline & $0 \%$ & $10 \%$ & $12 \%$ & $14 \%$ & $16 \%$ \\
\hline Bitumen & 139.68 & 125.71 & 122.92 & 120.12 & 117.33 \\
\hline Rubber additive & - & 5.04 & 6.05 & 7.06 & 8.06 \\
\hline Total & 139.68 & 130.75 & 128.97 & 127.18 & 125.40 \\
\hline
\end{tabular}

Source: author's work.

Tables 2, 3, and 4 show that some savings can be made regardless of the rubber additive used (in the range considered). First, the rear savings in asphalt, and second, differences result from the prices of the materials. Replacing $10 \%$ of the binder with $10 \%$ of the rubber additive means the total cost of the binder is lower by $6.39 \%$ (in comparison with the values determined for the binder not subjected to modification). The $12 \%$ rubber waste content in asphalt is a $7.67 \%$ lower expenditure, while the use of $14 \%$ waste material is a cost reduction of almost $9 \%$ (8.95\%). The presence of $16 \%$ of disintegrated rubber waste from worn vehicle tyres represents savings of $10.23 \%$. 
Tables 2, 3, and 4 are lists of binder costs, assuming that disintegrated rubber waste will be purchased at the price of 700 PLN per Mg and "introduced" into the binder in ratio, for example, $10 \%$ of binder $-10 \%$ of rubber additive. However, each mixture has a different binder content, and the use of rubber and asphalt binder salon requires redesigning the entire asphalt mixture each time. Besides, among the production costs, despite the significant share of costs and quantities of "input" materials, the manufacturing costs strictly depending on the temperature are also not insignificant. The typical mixture has a production temperature of $150^{\circ} \mathrm{C}$, while the production temperature of the asphalt mixtures with rubber is $180^{\circ} \mathrm{C}$. It looks similar for the range of effective compaction temperatures, which for the typical asphalt is between 95 and $115^{\circ} \mathrm{C}$, while for asphalt modified with crumb rubber waste, it is between $120^{\circ} \mathrm{C}$ and $140^{\circ} \mathrm{C}$. The literature (Stefańczyk \& Mieczkowski, 2006) indicates that increase of production temperature of the asphalt mixtures beyond the limits of $140-160^{\circ} \mathrm{C}$ causes a number of negative ecological, technical, and economic phenomena, including in particular: pollution of the atmosphere with hydrocarbon fumes, overheating of the bituminous binder leading to unfavourable structural changes, premature ageing of the pavement, and excessive consumption of driving materials.

\section{Conclusions}

Rubber derived from worn vehicle tyres (the most numerous group of rubber waste) of very good strength, mechanical, acoustic, or thermal properties is being reused more and more often. Road construction offers many opportunities to use recycled materials. Among various ways of utilising rubber waste, there are asphalt mixtures with their addition, introduced by two methods, dry or wet. The dry method consists in adding rubber granulate to the mineral mixture in order to replace part of the aggregate, while the wet method consists in modifying the binder with rubber dust beforehand and introducing the finished rubber and asphalt binder into the mineral mixture. Another application of worn tires in Polish road construction is their use in the form of rubber granulate in the poroelastic pavement. Another possibility is to develop non-expensive, environmentally friendly, and innovative materials derived from recycled vehicle tyres for backfilling the bridge abutments.

The "second life" of a tyre is also a financial and economic aspect, which has been considered to replace the binder with the rubber. The analysis, with the assumptions made, allowed for concluding that with an increase in the content of the rubber additive the cost of the binder changes. Replacing $10 \%$ of the binder with $10 \%$ of the rubber additive means a total cost of the binder 
is lower by $6.39 \%$ (in comparison with the values determined for the binder not subjected to modification). The $12 \%$ rubber waste content in asphalt is a $7.67 \%$ lower expenditure, while the use of $14 \%$ waste material is a cost reduction of almost $9 \%$ (8.95\%). The presence of $16 \%$ of disintegrated rubber waste from worn vehicle tyres represents savings of $10.23 \%$.

\section{References}

Adhikari, B., De, D., Maiti, S., 2000. Reclamation and recycling of waste rubber. Progress in Polymer Science, 25, 909-948, https://doi.org/10.1016/S0079-6700 (00)00020-4.

Amari, T., Themelis, N.J., Wernick, I.K., 1999. Resource recovery from used rubber tires. Resources Policy, 25, 179-188, https://doi.org/10.1016/S0301-4207(99) 00025-2.

Council Directive 99/31/EC of April 261999 on the landfill of waste.

Directive 2000/53/EC of the European Parliament and of the Council of September 18,2000 , on end-of-life vehicles.

Fang, Y., Zhan, M., Wang, Y., 2001. The status of recycling of waste rubber. Materials \& Design, 22, 123-128, https://doi.org/10.1016/S0261-3069(00)00052-2.

Fazli A., Rodrigue D., 2020. Waste Rubber Recycling: A Review on the Evolution and Properties of Thermoplastic Elastomers. Materials13 (3), 782; https://doi. org/10.3390/ma13030782.

Fukumori, K., Matsushita, M., Okamoto, H., Sato, N., Suzuki, Y., Takeuchi, K., 2002. Recycling technology of tire rubber. JSAE Review, 23, 259-264, https://doi. org/10.1016/S0389-4304(02)00173-X.

Ilkılıç, C., Aydın, H., 2011. Fuel production from waste vehicle tires by catalytic pyrolysis and its application in a diesel engine. Fuel Processing Technology, 92, 11291135, https://doi.org/10.1016/j.fuproc.2011.01.009.

Informacja miesięczna o stawkach robocizny oraz o cenach wybranych robót, materiałów i sprzętu w październiku 2021r. (2021). Sekocenbud - Błyskawica nr 10/2021, Ośrodek Wdrożeń Ekonomiczno-Organizacyjnych Budownictwa „Promocja”, Warszawa.

Informacja o cenach materiałów budowlanych w IV kwartale 2021r. Sekocenbud Zeszyt nr 57/2021. Ośrodek Wdrożeń Ekonomiczno-Organizacyjnych Budownictwa „Promocja”, Warszawa.

Kaloush, K., Zborowski, A., Sotil-Chávez, A., Abojaradeh, M., Way, G., 2003. Material characteristics of asphalt rubber mixtures. En: Sousa, J. B (Ed.). Proceedings of the Asphalt Rubber 2003 Conference, Brasilia, Brasil, 85-903997. Brasilia: Departamento de Estradas de Rodagem do Distrito Federal (DER/DF).

Karger-Kocsis, J., Mészáros, L., Bárány, T., 2013. Ground tyre rubber (GTR) in thermoplastics, thermosets, and rubbers. Journal of Materials Science, 48, 1-38, https:// doi.org/10.1007/s10853-012-6564-2.

Medina, N.F., Garcia R., Hadżirasouliha, I., Pilakoutas, K., Guadagnini, M., Raffoul, S., 2018. Composites with recycled rubber aggregates: Properties and opportunities in construction, Construction and Building Materials, 188, 884 - 897, https:// doi.org/10.1016/j.conbuildmat.2018.08.069. 
Plewa, A., 2014. Zastosowanie miału gumowego ze zużytych opon samochodowych w mieszankach mineralno-asfaltowych. Inżynieria Ekologiczna, 40, 217-227 doi: 10.12912/2081139X.84.

PERSUADE (Poroelastic Road Surface: an innovation to Avoid Domages to the Environment).

Radziszewski, P., Sarnowski, M., Król, J. B., Kowalski, K. J., Ruttmar, I., Zborowski, A., 2017. Właściwości asfaltów modyfikowanych gumą i mieszanek mineralno-gumowo-asfaltowych. Wydawnictwa Komunikacji i Łączności.

Ramarad, S., Khalid, M., Ratnam, C., Chuah, A.L., Rashmi, W., 2015. Waste tire rubber in polymer blends: A review on the evolution, properties and future. Progress in Materials Science,72, 100-140, https://doi.org/10.1016/j.pmatsci.2015.02.004.

Rozporządzenie Ministra Środowiska z dnia 4 listopada 2014 r. w sprawie standardów emisyjnych dla niektórych rodzajów instalacji, źródeł spalania paliw oraz urządzeń spalania lub współspalania odpadów (Dz.U. 2014 poz. 1546).

SEPOR - Safe, Environmentally Friendly Poroelastic Road Pavement.

Shah, J., Jan, M.R., Mabood, F., 2007. Catalytic conversion of waste tyres into valuable hydrocarbons. Journal of Polymers and the Environment, 15, 207-211. https:// doi.org/10.1007/s10924-007-0062-7.

Singh, N., Hui, D., Singh, R., Ahuja, I., Feo, L., Fraternali, F., 2017. Recycling of plastic solid waste: A state of art review and future applications, Composites Part B: Engineering,115,409-422,https://doi.org/10.1016/j.compositesb.2016.09.013.

Stefańczyk, B., Mieczkowski, P., 2006. Ekologiczne i techniczne efekty stosowania dodatków powierzchniowo-aktywnych substancji podczas produkcji mieszanek mineralno-asfaltowych. Seminarium Polsko-Niemieckie, Szczecin 26-27.10.2006.

Sybilski, D., 2009. Zastosowanie odpadów gumowych w budownictwie drogowym, Przegląd Budowlany, 5, 37-44.

Ustawa z dnia 27 kwietnia 2001 r. o odpadach (Dz.U. 2001 nr 62 poz. 628).

Ustawa z dnia 11 maja 2001 r. o obowiązkach przedsiębiorców w zakresie gospodarowania niektórymi odpadami oraz o opłacie produktowej (Dz.U. $2001 \mathrm{nr} 63$ poz. 639).

Ustawa z dnia 19 grudnia 2002 r. o zmianie ustawy o odpadach oraz niektórych innych ustaw (Dz.U. 2003 nr 7 poz. 78).

Ustawa z dnia 30 lipca 2004 r. o międzynarodowym obrocie odpadami (Dz.U. 2004 nr 191 poz. 1956).

Ustawa z dnia 20 stycznia 2005 r. o recyklingu pojazdów wycofanych z eksploatacji (Dz.U. 2005 nr 25 poz. 202).

Van Beukering, P.J., Janssen, M.A., 2001. Trade and recycling of used tyres in Western and Eastern Europe. Resources, Conservation and Recycling,33, 235-265, https://doi.org/10.1016/S0921-3449(01)00082-9.

Wymagania Techniczne WT - 2 2014. Nawierzchnie asfaltowe na drogach krajowych. Załącznik do zarządzenia Nr 54 Generalnego Dyrektora Dróg Krajowych i Autostrad z dnia 18.11.2014 r. 